\title{
PHENOMENOLOGICAL ANALYSIS OF THE ROLE OF GEOMETRIC FEATURES IN THE FORMATION OF THE STRUCTURE AND PROPERTIES OF THE MATERIAL
}

\author{
${ }^{1}$ Kolesnikov A.V., Ph.D., Associate Professor, \\ kolesnikovandrey2791@ gmail.com, ORCID: 0000-0001-8737-0933 \\ ${ }^{1}$ Semenova S.V., Ph.D., Associate Professor, \\ semenovablacksea@gmail.com, ORCID: 0000-0002-5309-5854 \\ ${ }^{1}$ Kirilenko G.A., Assistant, \\ galahimia@gmail.com, ORCID: 0000-0001-9377-1530 \\ ${ }^{1}$ Odessa State Academy of Civil Engineering and Architecture \\ 4, Didrikhson str., Odessa, 65029, Ukraine
}

\begin{abstract}
The paper discusses the reasons for the decrease in the strength of the composite material in relation to the theoretical. A hypothesis is put forward according to which, along with the known reasons; in particular, the presence of internal interfaces, and together with them, the processes near the forming geometric features that arise during the structure formation of the binder paste can act as reasons for the decrease in strength. To simulate the occurrence of features in composite binder paste, the concept of the local formation of new growth on the nuclei of a new phase present in the binder paste - layers of a hydrated binder on the surface of its grains - is used. According to the proposed model, the growth of a new phase occurs according to the mechanism associated with the formation of a wave front. The wave front also undergoes metamorphosis, as a result of which its features are formed, near which structural defects are concentrated. Another type of geometric features is hidden interfaces, which are formed as a result of opposite growth of wave fronts and their contact. The proposed mechanism is confirmed by the data of a microscopic study of the processes of structure formation of a gypsum binder - the formation of contact surfaces of the crystalline phase with different geometric and structural properties is observed on a model sample. As one of the main reasons for the occurrence of high concentrations of microcracks and other stress concentrators near hidden interfaces of the two types, the coexistence of solid phases with different structural characteristics in these regions is considered (there is a mismatch of the structural order parameters near the forming interfaces), as a result of which the strength decreases. This fact also explains the observed decrease in the ordering of the structure of the material in these areas. On the basis of the considered mechanisms of the formation of structural features leading to the destruction of the sample, methods are proposed for controlling the formation of the structure of the material, in particular, the targeted local introduction of solid phase nuclei into the binder paste.
\end{abstract}

Keywords: strength, theoretical strength, geometric structure, hardening, binder paste, wave front, gypsum.

Introduction. The main task of building materials science is to obtain building composite materials with a given set of properties, the most important of which are their strength characteristics. The maximum achievable tensile stress at break for a composite material, determined on the basis of the strength of the chemical bonds of the molecules of its constituents, will be called the theoretical strength by analogy with the theoretical strength of crystals [1]. Approximation of strength values to the theoretical limit is carried out by selecting the optimal composition and structure. However, a real approximation to the level of theoretical strength is difficult to achieve [2]. There are several reasons for the drop in strength in relation to the maximum theoretical level. One of the most significant is the presence of an internal structure in any solid, and especially in a composite material, which is not taken into account during calculating the theoretical strength. Composite materials with a stochastic hierarchical structure are characterized by the partial contributions of substructures of different scale levels to the strength reduction. 
The elements of the structure, hereinafter referred to as the structure of destruction, is the inner surface of the division, time and cracks, the formation under certain conditions (in particular, in the presence of internal and loading stresses under operating conditions), the elements actively participate in the processes of destruction [3], however, with their insignificant contains (up to 5\%) the strength of a rigid body for several years. Such structural elements appear and act in close connection with the geometric features of the samples and structures under study, which is a clear manifestation of consistency in materials science [4]. The analysis of the relationship between the geometric features of the forming composite and its strength characteristics can be carried out in many ways at several scale levels [5]. The paper assumes that at the mesoscopic level it is possible to describe the role of geometric features based on the minimum number of initial model assumptions.

For a number of binders and composites based on them, their total process of structure formation includes the stage of growth of neoplasms in accordance with crystallization mechanisms, followed by the formation of coagulation, point and phase contacts, which is most typical for gypsum materials. Such materials and the corresponding composites are characterized by the possibility of growth processes of new formations in the form of a solidification front, which has a geometric character of a wave front. Growth is carried out by a chain mechanism: neoplasms form crystallization surfaces of the next layer, and then the process is repeated [6]. During their propagation, wave fronts are capable of forming geometric features, and with their opposite growth, (hidden) interfaces are formed and, as a result, areas with the highest concentration of defects, internal interfaces, cracks - elements of the fracture structure are formed. Controlling the dynamics and geometry of the growing phase (in particular, in the form of a wave front) and minimizing the number of elements of the fracture structure are the way to improve the strength characteristics of the material.

Analysis of recent research. Theoretical strength is an important value in the field of materials science, indicating the strength resource of the material under consideration (of both inorganic and organic nature - polymers). It is calculated based on the assumptions of a homogeneous material structure, the absence of defects, cracks, pores and internal interfaces [1]. During calculating the theoretical strength, most often only the inhomogeneity of the material due to its molecular structure is taken into account [2]. The calculation uses the potentials of interatomic interaction, for example, the Mie potential (1):

$$
\mathrm{u}(\mathrm{r})=-\frac{\mathrm{a}}{\mathrm{r}^{\mathrm{m}}}+\frac{\mathrm{b}}{\mathrm{r}^{\mathrm{n}}}
$$

where $\mathrm{n}>\mathrm{m}, \mathrm{a}, \mathrm{b}$ - selected or calculated parameters of the potential, the first term corresponds to the force of attraction, the second - to the force of repulsion. The bond strength is estimated by the strength of the interaction of two atoms (2):

$$
\mathrm{f}=-\frac{\mathrm{du}(\mathrm{r})}{\mathrm{dr}} \text {. }
$$

If we take into account that there are $\mathrm{N}$ bonds per $1 \mathrm{~cm}^{2}$, we obtain an estimate of the theoretical strength [7] (3):

$$
\sigma=N|f|
$$

A more accurate calculation takes into account interactions over all pairs of atoms. The determination of the interatomic interaction can be carried out on the basis of ab initio quantum chemical calculations [8].

Since the structure of the composite is not known exactly, it is difficult to determine the theoretical strength. This value, however, can be estimated. The theoretical tensile strength at break can be estimated using the Orowan formula [1] (4):

$$
\sigma_{\mathrm{m}}=\left(\alpha \mathrm{E} / \mathrm{r}_{0}\right)^{\frac{1}{2}},
$$

where $\alpha$ - free surface energy of a solid body, $E$ - Young's modulus in the direction of extension, $r_{0}$ - distance between atoms in an undeformed state. Taking into account that the maximum elastic force corresponds to 10-20\% elongation of the interatomic bond, we have (5): 


$$
\sigma_{\mathrm{m}}=\chi_{0} \mathrm{E}
$$

In this case, on average, $\chi_{0} \approx 0,1$.

It should be noted once again that the theoretical ultimate strength is an elusive value. So, the analysis of the adhesion forces in the crystal of table salt leads to the values of the theoretical strength $\approx$ $200 \mathrm{kgf} / \mathrm{mm}^{2}$, at the same time the experimental values are $0.531 \mathrm{kgf} / \mathrm{mm}^{2}$ (about 400 times less). And only under special conditions in Ioffe's experiments [1] the strength reached $80 \%$ of the theoretical. Defects of the crystal lattice in single crystals, cracks, internal interfaces, pores in composite materials together form its structure of destruction, a three-dimensional "structure in the structure" of the material, consisting of internal observed and hidden interfaces, microcracks and defects, causing a decrease in strength in relation to the maximum. The fracture structure, in addition, is closely related to the geometric structure of the test sample [9]. One of the ways to describe the relationship between the fracture structure and geometric properties at the mesoscopic level can be explained on the basis of the scientific approach of A.N. Kolmogorov. In the so-called $\beta$-model [10], all crystals-nuclei appear in the mother liquor at the initial moment of time (for example, due to the addition of $\mathrm{CaSO}_{4} \cdot 2 \mathrm{H}_{2} \mathrm{O}$ nuclei to the binder paste). The growth of crystals of new formations is carried out starting from the surface of the nuclei of a new phase already present in the binder dough. It was shown in [11] that, under experimental and practical conditions, the nuclei of a new phase are introduced with binder grains on their surface. For these two models, the Kolmogorov equations for the fraction of the mother (noncrystallized) medium q have the form (6):

$$
\mathrm{q}(\mathrm{t})=\exp \left(-\mathrm{c} \beta \mathrm{v}^{\mathrm{k}} \mathrm{t}^{\mathrm{k}}\right) \quad \mathrm{v}=\mathrm{const},
$$

where $\mathrm{k}$ - the dimension of the model (and of the growing crystal), $\mathrm{v}$ - the growth rate of the nuclei, $\mathrm{c}$ - the shape factor of the nuclei. In this model, the growth of nuclei of a new phase occurs in the form of a wave front obeying the general regularity of the propagation of a disturbance in an active medium [12]. In particular, for the case under consideration, Fermat's principle was effected [9]. If the dynamics of the formation of the solid phase during solidification from the position of the considered model assumptions described is relatively simple (e.g., on the base (6) [11]), then to predict the strength characteristics of the forming composite based on its geometric features are much more complicated. One of the phenomenological approaches applicable for this purpose was proposed in the work under consideration.

The purpose of the study. The aim of the work is to develop a conceptual model for the formation of the strength properties of composite materials based on its mesoscopic structural and geometric characteristics. The corresponding tasks are the development of ideas about the hardening process about the propagation of the crystallization front in the active medium formed in the binder paste, and the subsequent interaction of the forming wave fronts and the formation of the fracture structure in the region of hidden interfaces and geometric features of wave fronts. An additional task is the experimental confirmation of the proposed model on the example of microscopic examination data of the hardening gypsum binder.

Objects and methods of the research. The object of research is microscopic preparations of the hardening gypsum binder paste as models of composite compositions, in the hardening of which crystallization processes prevail. These are, first of all, gypsum binders and compositions based on them. For cement compositions, the proposed approach can be applied on other (large) spatial scales; in this case, the hardening monomineral binder plays the role of a primary simplified model.

For microscopic research of hardening processes, a gypsum binder was used (gypsum G-5-B-II (DSTU B V. 2.7-82:2010) produced by Ivano-Frankivsk cement). The water-gypsum ratio was taken equal to 1 (taking into account the observation under the conditions of a microscopic preparation). The formulation was an initial binder brought into contact with the aqueous phase and placed on a glass slide. Observation and production of photographs was carried out on an installation based on a MIN-8 microscope at a total increasing of 70 times. The observation was carried out for $80 \mathrm{~min}$, the photographs were taken with a period of $3 \mathrm{~min}$, after $60 \mathrm{~min}$ - after $10 \mathrm{~min}$. In a series of photographs, images were identified that reflect the main features of the hardening process. 
The results of the research. The considered full-scale microscopic model of structure formation is a preparation of a water-gypsum dispersion, hardening under quasi-two-dimensional conditions. Crystals of gypsum dehydrate $\mathrm{CaSO}_{4} \cdot 2 \mathrm{H}_{2} \mathrm{O}$ can be clearly distinguished from about 18 minutes. The process of dissolution of the initial binder material occurs simultaneously with dispersion. The hardening product is dispersed particles surrounded by crystals of gypsum dehydrate.

It is characteristic that under conditions of moderate tightness (at the initial moment, the volume of the solid phase approximately corresponds to the free volume), most of the neoplasms are formed on the already existing nucleus located on the surface of the particles of semi-aqueous gypsum introduced into the binder paste. In the case of gypsum, under equilibrium moisture conditions, the surface layers have already been hydrated to a large extent. Thus, the stage of formation of crystalline nuclei is shortened or completely absent. Let us consider in more detail the stages of formation of the structure of the material, based on the results of microscopic examination. The first contacts of growing crystals of a new phase, which have of a point nature, occur at $21 \mathrm{~min}$. (Fig. 1, 3). At later stages, a network structure from interlocked crystals of gypsum dehydrate was formed (Fig. 1, 4-8).

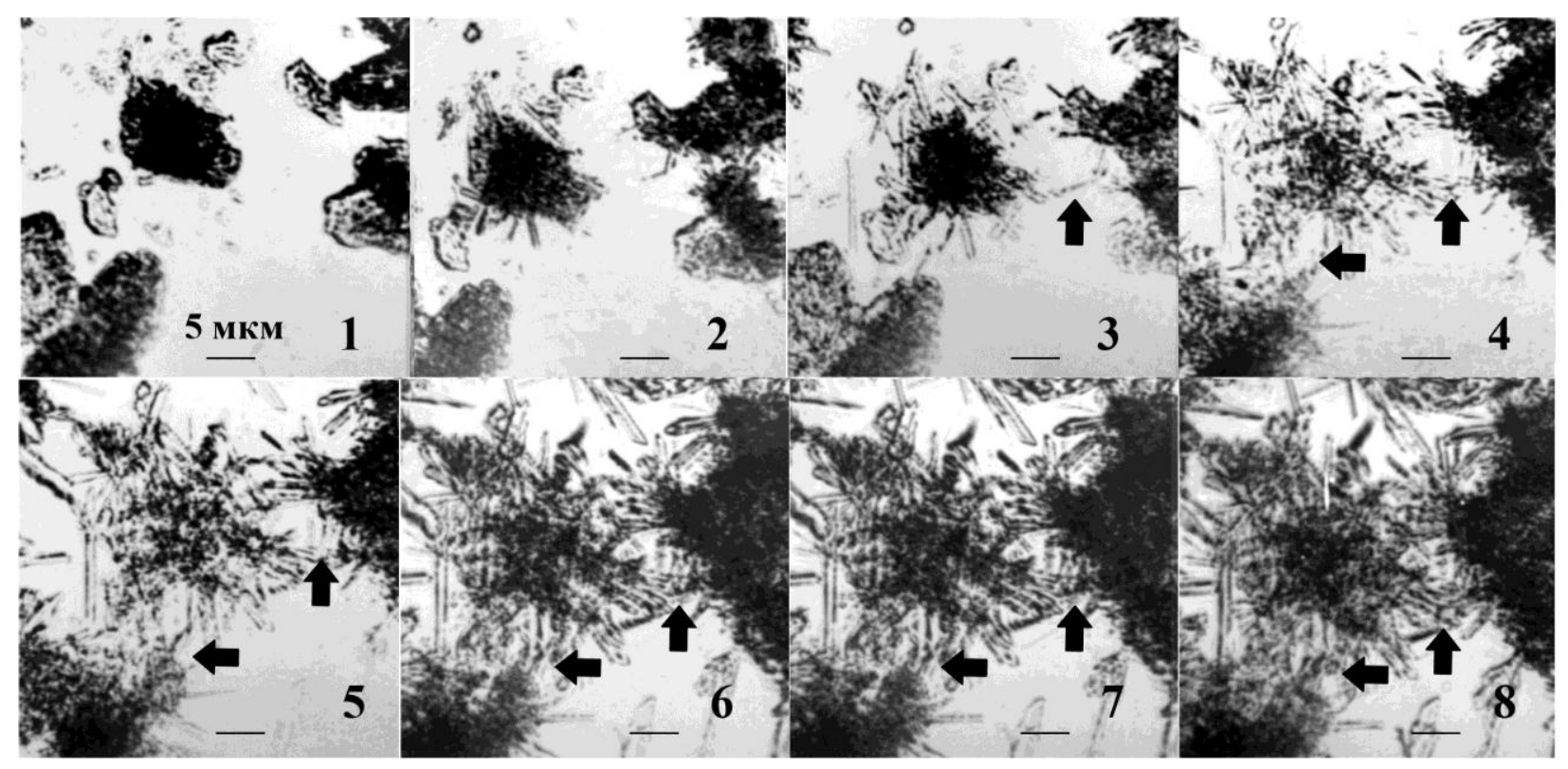

Fig. 1. Physical model of structure formation - hardening of gypsum dispersion.

Time from the moment of mixing: $1-3$ min; $2-18$ minutes; $3-21$ minutes; $4-27$ minutes; $5-33$ minutes; $6-39$ minutes; $7-45$ minutes; $8-80$ minutes. The black arrow marks the regions of formation of contacts between growing crystals of a new phase

In all observed cases discernible boundary, which corresponds to most of crystallization contacts. Under conditions of three-dimensional crystallization, this boundary corresponds to the contact of the growth fronts of a new phase, which is characterized by the presence of a significant number of defects, cracks, and other elements of the fracture structure. Such an area is a (hidden) interface. The geometric properties of the crystals of the new phase on both sides of this surface are different. Mostly different crystal orientations are observed near the interfaces.

A simplified model of the considered hardening system, taking into account the main observable facts, can be represented using the following scheme. The nucleus of the new phase, introduced into the binder paste directly or on the surface of the grains of the original binder, are the centers of structure formation 1 (Fig. 2). From their surface in the volume of binder paste 2 (Fig. 2), the process of growth of hydrated phase 3 began (Fig. 2). The process propagates in the form of a wave front. The contact of the growth fronts is accompanied by the appearance of hidden interfaces 4 (Fig. 1). They are characterized by weak orderliness and the presence of structural elements of destruction (microcracks, internal boundaries). From the standpoint of the proposed conceptual model, in these areas self-

Bulletin of Odessa State Academy of Civil Engineering and Architecture, 2021, no. 82, page 73-81 
generation and concentration of new structural elements was observed, which significantly affect the properties of the sample and its strength characteristics.

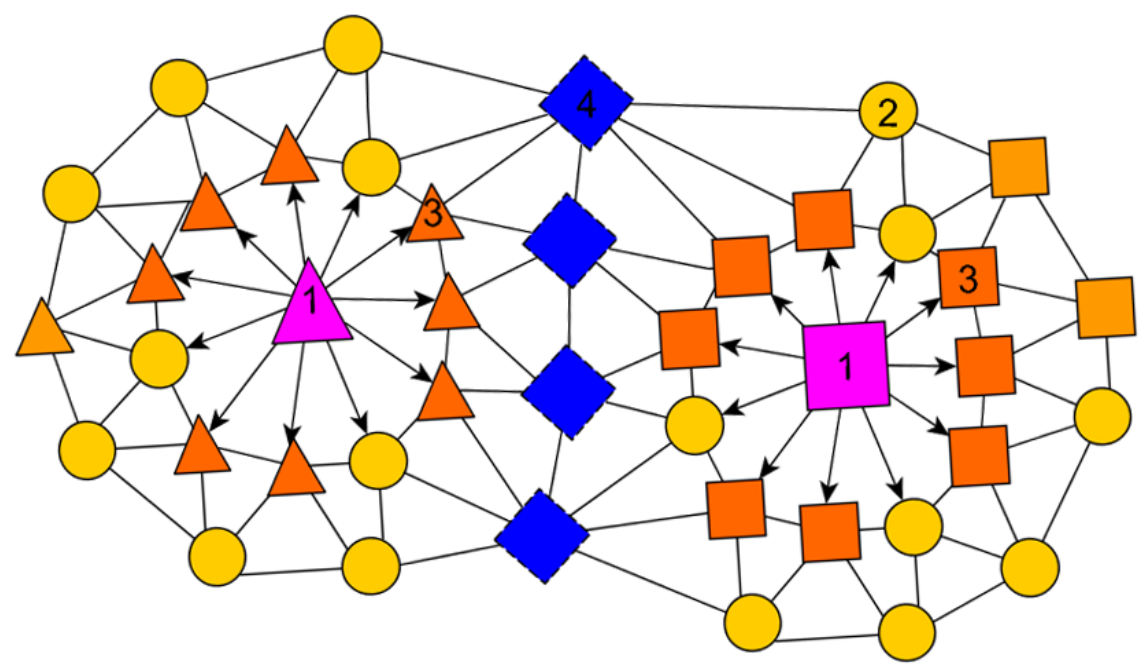

Fig. 2. Formation of elements of the structure of destruction in the process of structure formation of the composite material: 1 - structure-forming particles; 2 - unstructured part of the dispersed system; 3 - the phase of neoplasms; 4 - (hidden) interface

The effect of disordering in these regions (Fig. 1) can be interpreted based on ideas about the structural difference of crystals growing from different structure-forming centers (squares and triangles in Fig. 2). Under conditions of dense spatial arrangement of binder grains in concentrated dispersions and highly filled compositions; the probability of the considered mechanism (hindered transfer processes) increases.

Along with the considered geometric feature, another object capable of concentrating elements of the structure of destruction may be the features of the wave front from one structureforming particle. It is convenient to interpret the role of the features of the growth wave fronts proceeding from the following formal assumptions:

1. A composite material containing a binder, aggregate, fillers and additives can be simplified as a passive dispersed phase scatter in a dispersion medium corresponding to the binder dough.

2. The medium consists of active bistable elements, two states of which correspond to: $1-\mathrm{a}$ seized binder and $0-$ a binder component in a plastic-viscous state.

3. The setting process is considered as a switching wave in this medium, which is simplified in Fig. 3.

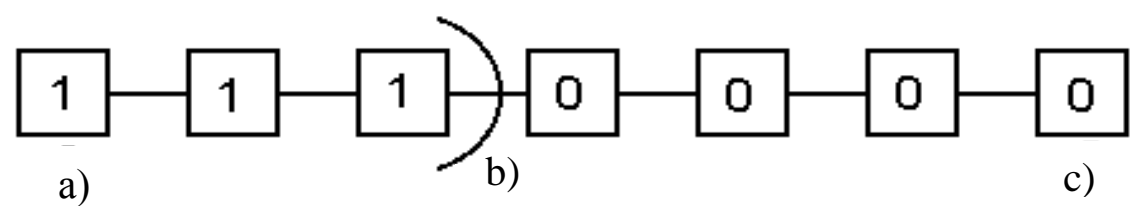

Fig. 3. The setting process as a switching wave:

$\mathrm{a}$ - model solid phase; $\mathrm{b}$ - plastic-viscous mass of the binder; $\mathrm{c}$ - front of switching (hardening)

Under the considered conditions, the hardening wave obeys the Huygens principle. Let's give equation of the hardening wave front (7):

$$
S(X, t)=0,
$$

where $X=\{x, y, z\}$ - spatial coordinates. Points corresponding to surface (3) are sources of secondary hardening waves. The position of the propagating front is set by the envelope of all secondary fronts (8) (Fig. 4):

$$
S(X, t+d t)=0
$$




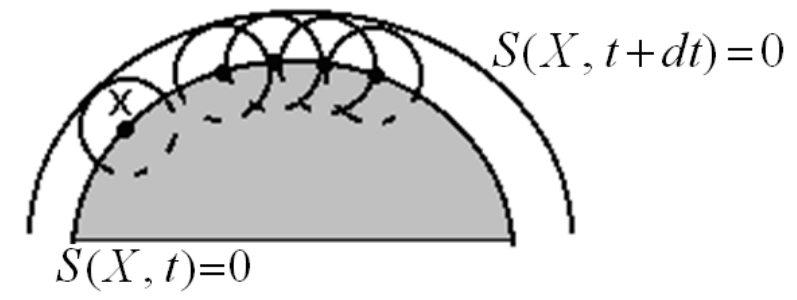

Fig. 4. Huygens principle of propagation of secondary waves for hardening processes

For systems of this kind, Fermat's "optical" principle about the minimum propagation time of hardening processes turns out: if hardening, propagating from point $\mathrm{A}$ in all possible directions, has already reached along some road to point $\mathrm{B}$, then all other roads connecting these points along which hardening takes longer, no longer matter.

One of the advantages of the considered approach is the possibility of describing the processes in the systems under consideration using the Hamilton - Jacobi equations (9) and the canonical Hamilton equations.

$$
\frac{\partial S}{\partial t}+H\left(x, y, z, \frac{\partial S}{\partial x}, \frac{\partial S}{\partial y}, \frac{\partial S}{\partial z}\right)=0,
$$

where $\mathrm{H}-$ Hamilton function determined by the properties of the medium. Equation (9) specifies the propagation of hardening processes in the form of wave fronts.

In a medium with complex geometrical characteristics, wave fronts have specific features and undergo metamorphoses [13] (Fig. 5). One of the typical features of the wave front is the "dovetail" (A3), which has edge of regression and self-intersection curves (Fig. 5, dotted line). Let's consider the processes taking place in the composite material. In the region of the curves of self-intersection of the forming wave front, the growing wave fronts of the solid phase with different structural characteristics come into contact.

The feature of the material, corresponding, in particular, to the edge of the self-intersection of the wave front (Fig. 5, dotted line) is one of the varieties of "hidden" interfaces (not detected by optical methods).
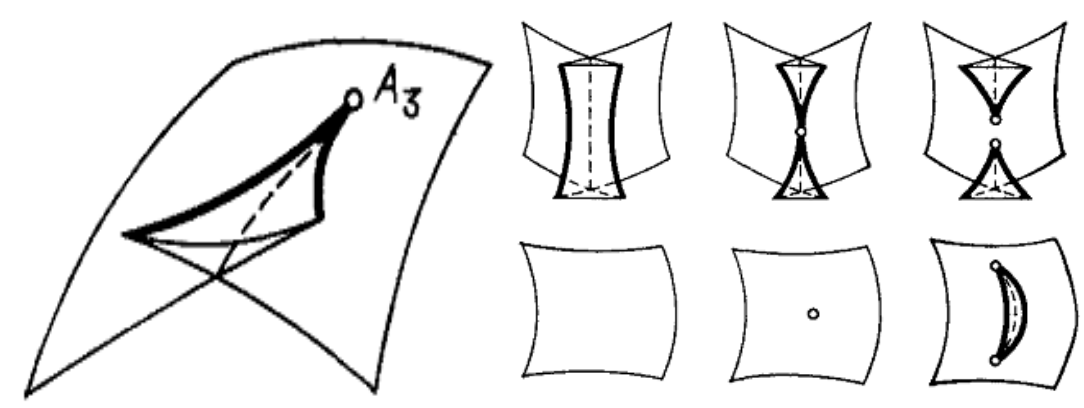

Fig. 5. Typical features and metamorphoses of wave fronts: dotted line - curves of self-intersection; bold lines - cusp edges

Here, self-generation and grouping of stress concentrators of different scales, which are elements of the fracture structure, should be expected (Fig. 6, 3).

Argumentation carried out in a similar sequence allows one to search for elements of the fracture structure (stress concentrators) near the features of the hardening wave fronts. The caustics associated with the spread of hardening processes are probably capable of performing a similar function.

Under the conditions of a dense spatial arrangement of binder grains in concentrated dispersions and highly filled compositions, the probability of the implementation of the considered mechanism (hindered transfer processes) increases. 

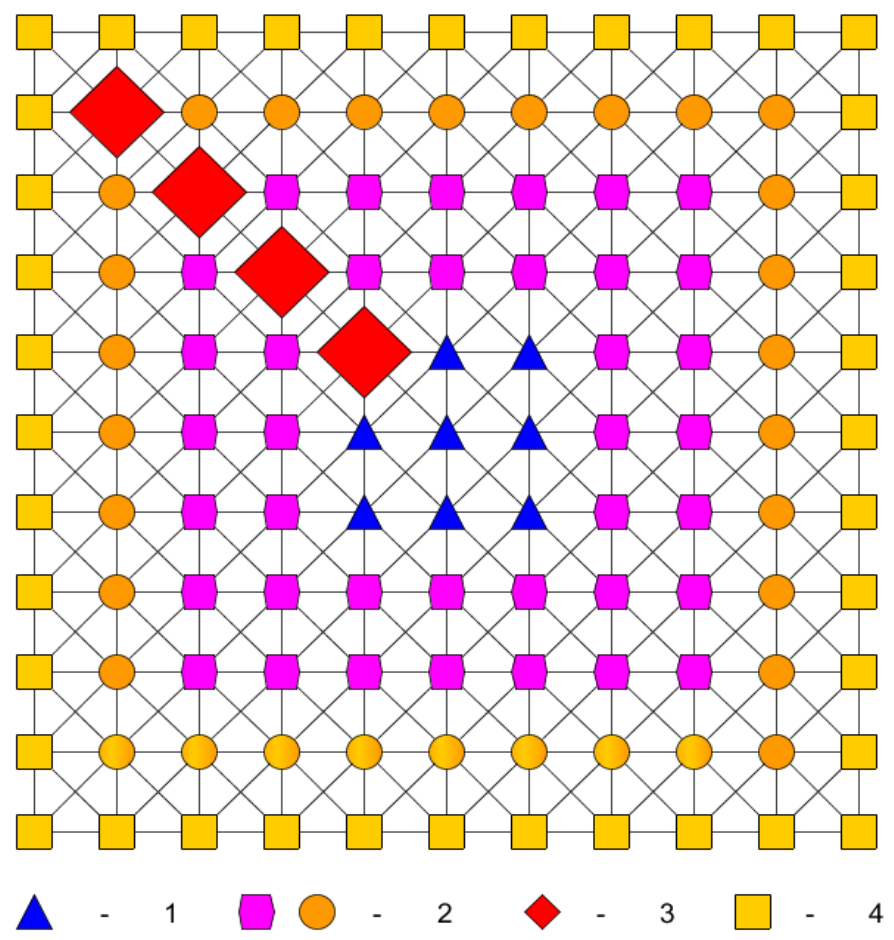

Fig. 6. Scheme of the formation of structural features of the growth wave fronts of the hydration phase: 1 - the nucleus of a new phase; 2 - structural elements of the new phase; 3 - a feature of the growth

front of neoplasms; 4 - elements of the original dispersed system

The purposeful organization of the hardening structure on the proposed theoretical basis can be carried out by several methods: using forms of a given geometry, which can be realized on significant spatial scales and the formation of active surfaces by creating ready-made crystallization centers on them (for example, coating an aggregate of a given geometry with a layer of gypsum dehydrate and the formation of gypsum composite based on it). The theoretical and calculated aspects of the formation of the geometric structure of stress concentrators, as well as options for controlling the structure formation by geometric methods, can be based on the considered conceptual scheme, which is the subject of future research.

Conclusions. An experimental-conceptual model of the influence of the geometric features of composite materials on its strength characteristics was considered and argued. It is shown that the elements of the fracture structure - explicit, optically detectable, hidden internal interfaces and cracks - are able to concentrate in the area of geometric features that arise during the period of structure formation. Geometric features of two types are distinguished: the contact of the wave fronts of the growing phase of hydrates and the features of the wave front of hardening arising during its metamorphoses. The heterogeneity of the structural characteristics of the new phase near them is considered as one of the main reasons for the formation of a fracture structure in the regions of the corresponding surfaces. Variants of controlling the processes under consideration by purposefully coordinating the introduction of crystallization centers into the hardening composite binder have been proposed.

\section{Reference}

[1] G.M.Bartenev, Prochnost' i mekhanizm razrusheniya polimerov. M.: Khimiya, 1984.

[2] V.Ye Gul', Struktura i prochnost' polimerov. 3-ye izd., pererab. i dop., M.: Khimiya, 1978.

[3] V.N. Vyrovoy, V.G. Sukhanov, O.A. Korobko, "Treshchiny i ikh rol' v zhiznennom tsikle materiala stroitel'nykh konstruktsiy", Mekhanika razrusheniya betona, zhelezobetona $i$ drugikh stroitel'nykh materialov: materialy mezhdunarodnoy nauchnoy konferentsii $i$ zasedaniya Nauchnogo soveta otdeleniya stroitel'nykh nauk RAASN. Sankt-Peterburg, 2016, pp. 22-26. 
[4] V.N. Vyrovoy, V.S. Dorofeyev, V.G. Sukhanov, Kompozitsionnyye stroitel'nyye materialy $i$ konstruktsii. Struktura, samoorganizatsiya, svoystva. Odessa: «TES», 2010.

[5] V.G. Sukhanov, V.N. Vyrovoy, O.A. Korobko, Struktura materiala v strukture konstruktsii. Odessa: Poligraf, 2016.

[6] V.B Ratinov, L.YA. Zabezhinskiy, T.I. Rozenberg, "K voprosu o teorii tverdeniya mineral'nykh vyazhushchikh veshchestv", Sb. trudov NIIZHB, vol. 1, pp. 3-34, 1957.

[7] Z. Jin, C. Sun, Fracture mechanics. Waltham, MA: Academic Press, 2011.

[8] J. Pokluda, M. Cern, P. Sandera, M. Sob, "Calculations of theoretical strength : State of the art and history", Journal of Computer-Aided Materials Design, 11, pp.1-28, 2004.

[9] C. Nielsen, A.V. Amirkhizi, S.Nemat-Nasser, "The effect of geometry on fracture strength measurement using DCDC samples", Engineering Fracture Mechanics 91, pp. 1-13, 2012.

[10] V.Z. Belen'kiy, Geometriko-veroyatnostnyye modeli kristallizatsii. Fenomenologicheskiy podkhod. Moskva, Nauka, 1980.

[11] A.V. Kolesnikov, S.V. Semenova, N.V. Kazmírchuk, G.A. Kirilenko, "Doslídzhennya strukturoutvorennya gípsovikh kompozitív na osnoví rívnyan' Kolmogorova", Visnik Odes'koï derzhavnoï akademiï budivnictv ta arhitekturi, vol. 78, pp. 97-107, 2020.

[12] I.M. Gel'fand, S.V. Fomin, Variatsionnoye ischisleniye. M.: Gosudarstvennoye izdatel'stvo fiziko-matematicheskoy literatury, 1961.

[13] V.I. Arnol'd, Osobennosti kaustik i volnovykh frontov. M.: FAZIS, 1996.

\title{
ФЕНОМЕНОЛОГІЧНИЙ АНАЛІЗ РОЛІ ГЕОМЕТРИЧНИХ ОСОБЛИВОСТЕЙ У ФОРМУВАННІ СТРУКТУРИ І ВЛАСТИВОСТЕЙ МАТЕРІАЛУ
}

\author{
${ }^{1}$ Колесніков А.В., к.т.н., доцент, \\ kolesnikovandrey2791@ gmail.com, ORCID: 0000-0001-8737-0933 \\ ${ }_{1}^{1}$ Семенова С.В., к.т.н., доцент, \\ semenovablacksea@gmail.com, ORCID: 0000-0002-5309-5854 \\ ${ }^{1}$ Кириленко Г.А., асистент, \\ galahimia@gmail.com, ORCID: 0000-0001-9377-1530 \\ ${ }^{1}$ Одеська державна академія будівництва і архітектури \\ вул. Дідріхсона, 4, м. Одеса, 65029, Україна
}

Анотація. В роботі розглядаються причини зниження міцності композиційного матеріалу відносно до теоретичної. Було висунуто гіпотезу, згідно з якою поряд 3 відомими причинами, зокрема, наявністю внутрішніх границь розділу, і спільно з ними, в якості причин зменшення міцності можуть виступати процеси поблизу геометричних особливостей, що виникають при структуроутворенні в'яжучого тіста. Для моделювання виникнення особливостей в композиційному в'яжучому тісті застосовуються уявлення про локальне формування новоутворень на наявних в в'яжучому тісті зародків нової фази - шарів гідратованого в'яжучого на поверхні його зерен. Згідно запропонованої моделі, зростання нової фази відбувається за механізмом, пов'язаним з утворенням хвильового фронту. Хвильовий фронт також піддається метаморфозам, в результаті чого формуються його особливості, поблизу яких концентруються дефекти структури. Іншим видом геометричних особливостей $є$ приховані границі розділу, що формуються в результаті зустрічного зростання хвильових фронтів i ïх зіткнення. Запропонований механізм підтверджується даними мікроскопічного дослідження процесів структуроутворення гіпсового в'яжучого - на модельному зразку спостерігається формування поверхонь контакту кристалічної фази 3 різними геометричними та структурними властивостями. В якості однієї 3 основних причин виникнення високих концентрацій мікротріщин та інших концентраторів напружень поблизу прихованих границь розділу двох видів розглядається співіснування в цих областях твердих фаз з різними структурними характеристиками (спостерігається неузгодженість структурних параметрів порядку поблизу границь розділу, що формуються), в результаті чого знижується міцність. Цим фактом 
пояснюється також зниження впорядкованості структури матеріалу в цих областях. На основі розглянутих механізмів формування структурних особливостей, що призводять до руйнування зразка, пропонуються методи управління формуванням структури матеріалу, зокрема, цілеспрямоване локальне введенням зародків твердої фази в в'яжучий тісто.

Ключові слова: міцність, теоретична міцність, геометрична структура, твердіння, в'яжучий тісто, хвильовий фронт, гіпс.

\title{
ФЕНОМЕНОЛОГИЧЕСКИЙ АНАЛИЗ РОЛИ ГЕОМЕТРИЧЕСКИХ ОСОБЕННОСТЕЙ В ФОРМИРОВАНИИ СТРУКТУРЫ И СВОЙСТВ МАТЕРИАЛА
}

\author{
${ }^{1}$ Колесников А.В., к.т.н., доцент, \\ kolesnikovandrey2791@gmail.com, ORCID: 0000-0001-8737-0933 \\ ${ }_{1}^{1}$ Семенова С.B., к.т.н., доцент, \\ semenovablacksea@gmail.com, ORCID: 0000-0002-5309-5854 \\ ${ }^{1}$ Кириленко Г.А., ассистент, \\ galahimia@gmail.com, ORCID: 0000-0001-9377-1530 \\ ${ }_{1}^{1}$ Одесская государственная академия строительства и архитектуры \\ ул. Дидрихсона, 4, г. Одесса, 65029, Украина
}

\begin{abstract}
Аннотация. В работе рассматриваются причины снижения прочности композиционного материала по отношению к максимально возможной. Выдвигается гипотеза, согласно которой наряду с известными причинами, в частности, наличием внутренних границ раздела, и совместно с ними, в качестве причин уменьшения прочности могут выступать процессы вблизи формирующихся геометрических особенностей, возникающих при структурообразовании вяжущего теста. Для моделирования возникновения особенностей в композиционном вяжущем тесте применяются представления о локальном формировании новообразований на имеющихся в вяжущем тесте зародышах новой фазы - слоев гидратированного вяжущего на поверхности его зерен. Согласно предложенной модели, рост новой фазы происходит по механизму, связанному с образованием фронта твердения. Этот фронт, подобно волновым фронтам, подвергается метаморфозам, в результате чего формируются его особенности, вблизи которых самозарождаются и концентрируются такие элементы структуры, как трещины и внутренние границы раздела. Другим видом геометрических особенностей являются скрытые границы раздела, формирующиеся в результате встречного роста волновых фронтов и их соприкосновения. Предложенный механизм подтверждается данными микроскопического исследования процессов структурообразования гипсового вяжущего - на модельном образце наблюдается формирование поверхностей контакта кристаллической фазы с разными геометрическими и структурными свойствами. В качестве одной из основных причин возникновения высоких концентраций микротрещин и других концентраторов напряжений вблизи скрытых границ раздела двух видов рассматривается сосуществование в этих областях твердых фаз с разными структурными характеристиками (наблюдается рассогласование структурных параметров порядка вблизи формирующихся границ раздела), в результате чего снижается прочность. Этим фактом объясняется также наблюдаемое снижение упорядоченности структуры материала в этих областях. На основе рассматриваемых механизмов формирования структурных особенностей, приводящих к разрушению образца, предлагаются методы управления формированием структуры материала, в частности, целенаправленным локальным введением зародышей твердой фазы в вяжущее тесто.
\end{abstract}

Ключевые слова: прочность, теоретическая прочность, геометрическая структура, твердение, вяжущее тесто, волновой фронт, гипс.

Стаття надійшла до редакції 5.02.2021 